\title{
Use of buffered hypochlorite solution for disinfecting fibrescopes
}

\author{
D COATES, $*$ JANET E DEATH $\dagger$
} From the Disinfection Reference Laboratory, Central Public Health Laboratory, Colindale Avenue,
London NW9 5HT

SUMMARY The possible use of sodium hypochlorite solution buffered to $\mathrm{pH} 7.6$ and containing $100 \mathrm{ppm}$ available chlorine (av $\mathrm{Cl}$ ) for disinfecting fibrescopes was investigated. A flexible fibrescope experimentally contaminated with Pseudomonas putida, Mycobacterium fortuitum, or Bacillus subtilis spores was effectively disinfected within 10 min repeatedly and without any observable adverse effect on the instrument. The corrosive nature of buffered hypochlorite was investigated by immersing various fibrescope components and metal wires in solutions of different strength for long periods and examining them for damage. Stainless steel, platinum, glass, Teflon, polythene and epoxy resin were apparently unaffected whereas polyurethane, rubber and other metals tested were damaged to different extents. Buffered hypochlorite solutions may have many applications pertaining to the disinfection of items which are either thermolabile or require rapid effective disinfection.

Modern fibrescopes are intricate, delicate, thermolabile instruments inherently difficult to disinfect and sterilise under practical conditions of use. Because of their expense, an operator may have only one instrument available which may be required more than once during a list. Hence a rapid method of processing is required which ideally should produce a clean sterile instrument. Ethylene oxide can be used ${ }^{1-3}$ for sterilising fibrescopes between lists, but the process takes too long for use between patients on a list. Currently, most operators use liquid chemical disinfectants for decontaminating instruments between and during lists. A few disinfectants such as glutaraldehyde and sodium hypochlorite, possess appreciable sporicidal activity at room temperature and hence are potential sterilants. Currently $2 \%$ glutaraldehyde solution is widely used for disinfecting endoscopes, but Kelsey et $\mathrm{al}^{4}$ found that one commercial preparation (Cidex: Ethicon) was a poor sporicide in $3 \mathrm{~h}$ except when freshly activated, and the manufacturers recommend $10 \mathrm{~h}$ for sterilisation. Furthermore, glutaraldehyde is expensive and may cause sensitisation. Kelsey et al found that

*Present address: Public Health Laboratory, Preston Infirmary, Meadow Street, Preston, Lancashire PR1 6PS. $\dagger$ Present address: Microbiological Safety Reference Laboratory, PHLS Centre for Applied Microbiology and Research, Porton Down, Salisbury, Wiltshire SP4 0JG.

Accepted for publication 21 September 1981 freshly prepared mixtures of methanol and sodium hypochlorite were far more sporicidal than any of the proprietary products that they tested. Fifteen minutes immersion in a mixture containing $50 \%$ methanol and hypochlorite of $2000 \mathrm{ppm}$ available chlorine (av $\mathrm{Cl}$ ) was suggested for disinfection of heatsensitive instruments except those of plated metal.

As concentrated hypochlorite solutions are corrosive we investigated various alcohol/hypochlorite combinations hoping to find mixtures with equivalent sporicidal activity but with much reduced concentrations of alcohol and hypochlorite. 5 Subsequently, we investigated the effect of buffering mixtures to a lower $\mathrm{pH} .{ }^{6}$ The sporicidal activity of the hypochlorite component was increased so markedly that the potentiating effect of the alcohol component was no longer considered necessary. The activity of hypochlorite solution alone containing $100 \mathrm{ppm}$ av $\mathrm{Cl}$ and buffered to $\mathrm{pH} 7.6$ was found to be excellent and reasonably long-lasting; a 5-log reduction in viable count of Bacillus subtilis spores was achieved within $10 \mathrm{~min}$ by solutions up to at least a week old. Fresh solutions achieved a 5-log reduction in viable count of spores of Clostridium sporogenes, and vegetative cells of Pseudomonas aeruginosa, Proteus vulgaris, Escherichia coli, Staphylococcus aureus and Candida albicans within a minute. This paper describes laboratory tests performed to evaluate the possible use of this buffered hypochlorite solution for disinfecting fibrescopes. 


\section{Material and methods}

Spores of $B$ subtilis NCTC 10073 were used in sporicidal tests and vegetative cells of Mycobacterium fortuitum NCTC8573 and a wild strain of Pseudomonas putida isolated from a fibrescope were used in microbicidal tests. An aqueous test suspension of $B$ subtilis spores was prepared by the method of Beeby and Whitehouse ${ }^{7}$ and stored at $4^{\circ} \mathrm{C}$. A test suspension of $M$ fortuitum was prepared from a 72-hour culture in $10 \mathrm{ml} 1 \%$ peptone water incubated at $37^{\circ} \mathrm{C}$ by decanting off $8 \mathrm{ml}$ growth medium and resuspending the granular deposit in the remaining $2 \mathrm{ml}$ medium. A test suspension of $P$ s putida was prepared by culturing the organism in $10 \mathrm{ml} 1 \%$ peptone water incubated at $37^{\circ} \mathrm{C}$ for $24 \mathrm{~h}$.

Three disinfectants were used in tests: Cidexactivated glutaraldehyde solution (Arbrook); an unbuffered mixture of methanol, AnalaR (Hopkin and Williams Ltd) and sodium hypochlorite solution (BDH Ltd) containing (final concentrations) $25 \%$ methanol and $2000 \mathrm{ppm}$ av $\mathrm{Cl}$; and a sodium hypochlorite solution containing $100 \mathrm{ppm} \mathrm{av} \mathrm{Cl}$ buffered at $\mathrm{pH} 7.6$ using phosphate buffer. ${ }^{6}$

Tests on the sporicidal activity of disinfectants against $B$ subtilis spores in suspension were carried out in a water bath thermostatically controlled at $25^{\circ} \mathrm{C} \pm 0 \cdot 1^{\circ} \mathrm{C}$ by the method of Coates and Death. ${ }^{5} 6$ An $0.5 \%$ aqueous solution of sodium thiosulphate was used as inactivator for both the buffered hypochlorite solution and the unbuffered methanol/ hypochlorite mixture. ${ }^{5}$ Cidex was inactivated by $\geqslant 100$-fold dilution in $1 / 4$ strength Ringer's solution. ${ }^{8}$ For tests on buffered hypochlorite and methanol/ hypochlorite freshly prepared solutions were used. For tests on Cidex, solutions freshly activated (by addition of sodium bicarbonate powder), 7 days post activation, and 14 days post activation were used. Activated solutions were kept in closed bottles at $25^{\circ} \mathrm{C}$ over the 14-day test period. $\mathrm{pH}$ measurements were made using a Philips PW9418 pH meter. Available chlorine assays of hypochlorite solutions were made by an arsenite titration method. ${ }^{9}$

Tests on the activity of disinfectants against spores and vegetative bacteria within the biopsy channel of a fibrescope were carried out using a flexible oesophago-fibrescope model EF-L (Olympus Ltd). The biopsy channel of the fibrescope was contaminated by injecting test suspensions of spores or vegetative bacteria down the entire channel via the channel opening in the control section with the biopsy valve removed. The suspension was left in the channel for $60 \mathrm{~min}$ and then allowed to drain out gravitationally through the distal tip. Subsequently disinfection was carried out immediately or after overnight drying of the residual suspension within the channel. Pre- liminary experiments were performed to determine the number of recoverable organisms deposited in the channel by the contamination procedure. Immediately after contamination $50 \mathrm{ml}$ sterile distilled water were flushed down the channel via a cleaning attachment in the control section using a $50 \mathrm{ml}$ syringe and collected from the distal tip. After suitable serial deci-dilutions of the water in $1 / 4$ strength Ringer's solution, viable counts were made by the method of Miles and Misra ${ }^{10}$ using blood agar plates incubated at $37^{\circ} \mathrm{C}$ for $48 \mathrm{~h}$. After establishing the control numbers of test organisms recoverable from the channel after contamination the effects of various disinfection procedures were evaluated. First, the effect of aspirating known volumes of disinfectant up through the biopsy channel was investigated. Suction was provided by a vacuum pump connected via a liquid trap to the suction connection at the end of the universal cord of the fibrescope. An equal volume of disinfectant was distributed into two beakers. Disinfectant in one beaker was aspirated up through the distal tip of the insertion tube and along the biopsy channel. Disinfectant in the other beaker was aspirated up through the biopsy channel opening in the control section via a cleaning attachment. Thus the whole length of the biopsy channel was disinfected. Immediately after disinfection $50 \mathrm{ml}$ sterile distilled water (Cidex experiments) or $0.5 \%$ sodium thiosulphate (buffered hypochlorite experiments) were flushed down the channel via the cleaning attachment using a $50 \mathrm{ml}$ syringe and collected from the distal tip. Surviving organisms were enumerated by dilution and plating out as previously described or by membrane filtration where survival levels were low. Next, the effect of leaving buffered hypochlorite in the channel for increasing periods of time was evaluated, and then the effect of leaving buffered hypochlorite in the channel for short periods followed by aspiration of fresh hypochlorite up through the biopsy channel. Finally, the effectiveness of a combination of mechanical cleaning and buffered hypochlorite disinfection on organisms suspended in horse serum and left in the biopsy channel overnight was evaluated. Sterile inactivated horse serum $(5 \mathrm{ml})$ (Wellcome Reagents Ltd) was inoculated with either $B$ subtilis spores or $M$ fortuitum. $0.1 \mathrm{ml}$ stock spore suspension or $\mathbf{7 2}$ hour culture of $M$. fortuitum was added to the serum and viable counts performed. The inoculated serum was then aspirated up the biopsy channel via the distal tip, using a syringe connected to the cleaning attachment. After $15 \mathrm{~min}$ it was expelled by depressing the syringe plunger, removing the syringe, and allowing any excess serum todrain out of the insertion tube held vertically. After $15 \mathrm{~min}$ the tip was wiped dry and the fibre- 
scope placed in its carrying case and left overnight at room temperature. The next day cleaning and disinfection was carried out. A solution of soap flakes in warm water was freshly prepared and $500 \mathrm{ml}$ aspirated up the biopsy channel with the biopsy valve removed and a finger covering the biopsy channel aperture. The cleaning brush was passed up and down the channel once during this procedure (with suction off) and several times on completion. Next, $500 \mathrm{ml}$ sterile water were aspirated up the biopsy channel and $500 \mathrm{ml}$ up the cleaning attachment. Finally, $500 \mathrm{ml}$ buffered hypochlorite solution $(100 \mathrm{ppm}$ av $\mathrm{Cl})$ were aspirated up the biopsy channel and $500 \mathrm{ml}$ up the cleaning attachment. After disinfection $50 \mathrm{ml}$ sodium thiosulphate solution were flushed down the biopsy channel and collected at the distal tip for dilution and plating out as previously described.

The corrosive nature of buffered hypochlorite solutions was investigated by immersing fibrescope components and wires made from various metals in hypochlorite solutions for long periods and examining them for damage. The wire materials tested were stainless steel, spring steel, tinned copper, copper, galvanized iron, brass, phospho-bronze, two qualities of nichrome, and platinum. They were suspended in hypochlorite solutions of strengths $100 \mathrm{ppm}$ av $\mathrm{Cl}$ at $\mathrm{pH} 7 \cdot 8$, and $2000 \mathrm{ppm}$ av $\mathrm{Cl}$ at $\mathrm{pH} 11 \cdot 4$, and kept at $25^{\circ} \mathrm{C}$ for three months. Damage over this period was estimated by visual appearance and measurement of length and diameter of the wires and visual appearance of deposits in the solutions. Assays of available chlorine concentrations of the solutions were also made at intervals since a fall in available chlorine level compared with a control solution containing no wire indicates some reaction between the metal and the hypochlorite. The fibrescope component materials (Olympus Ltd) tested were polyurethane, rubber, araldite epoxy resin, stainless steel, glass, teflon and polythene. The materials were immersed in buffered hypochlorite solutions containing up to $500 \mathrm{ppm}$ av $\mathrm{Cl}$ for up to four months at room temperature. Each day the hypochlorite solution was replaced with fresh solution and materials were visually examined for damage. Availablechlorine assays were performed on solutions in which materials became damaged.

\section{Results}

WATER BATH EXPERIMENTS

The relative sporicidal activity of a buffered solution of dilute sodium hypochlorite, an unbuffered mixture of methanol and concentrated sodium hypochlorite, and activated Cidex solutions of increasing age, is shown in Fig. 1. It is clearly

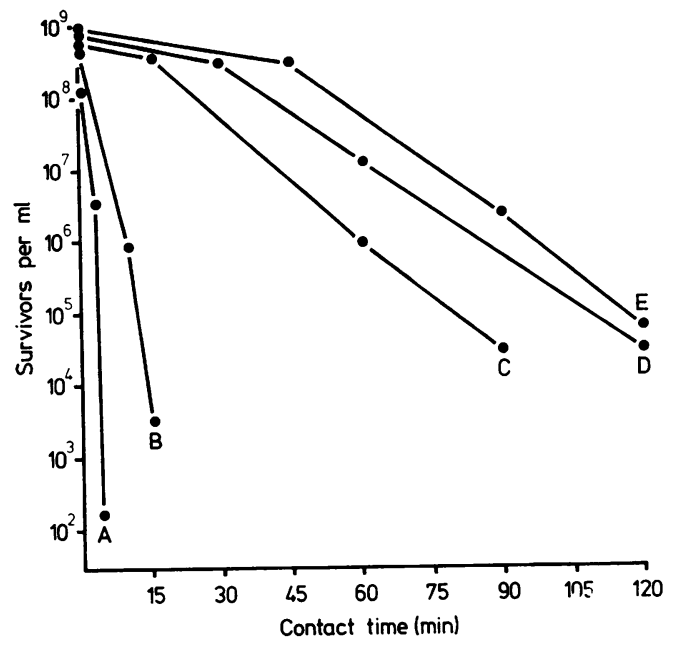

Fig. 1. Sporicidal activity of buffered hypochlorite, an unbuffered methanol/hypochlorite mixture, and Cidex solutions against $\mathrm{B}$ subtilis spores at $25^{\circ} \mathrm{C} . \mathrm{A}=$ hypochlorite of $100 \mathrm{ppm}$ av $\mathrm{Cl} \mathrm{pH} \mathrm{7.6;B}=25 \%$ methanol + hypochlorite of $2000 \mathrm{ppm}$ av $\mathrm{Cl} \mathrm{pH} \mathrm{11.4;}$ $C=$ Cidex freshly activated $p H$ 9.0; $D=$ Cidex 7 days old $p H 8 \cdot 0 ; E=$ Cidex 14 days old $p H 8 \cdot 0$.

demonstrated that in this test system the sporicidal activity of the buffered hypochlorite solution and of the unbuffered methanol/hypochlorite mixture was greatly superior to that of theCidex solutions. Whereas the buffered hypochlorite solution achieved a 5-log reduction of $B$ subtilis spores in about $5 \mathrm{~min}$, and the methanol/unbuffered hypochlorite mixture in about $15 \mathrm{~min}$, freshly activated Cidex solution took more than 90 minutes. Furthermore, Cidex solutions lost activity on storage after activation, accompanied by a fall in $\mathrm{pH}$. The $\mathrm{pH}$ of several samples of Cidex when freshly activated was in the range $\mathrm{pH} 8 \cdot 9-9 \cdot 0$. After a week this had fallen to $\mathrm{pH} 7 \cdot 8-8 \cdot 2$, but no further fall in $\mathrm{pH}$ occurred in the second week after activation.

\section{FIBRESCOPE EXPERIMENTS}

Preliminary experiments were performed to determine the number of test organisms, deposited in the biopsy channel by the contamination procedure, that were recoverable by the elution, dilution and plating out procedure. In eight experiments using $B$ subtilis spores the number of colony forming units per ml elutant ranged from $2.0 \times 10^{4}$ to $5.6 \times 10^{4}$ with a mean of $2.7 \times 10^{4}$. In eight experiments with $M$ fortuitum the number of colony forming units per ml elutant ranged from $3.0 \times 10^{4}$ to $1.9 \times 10^{5}$ with a mean of $9.4 \times 10^{4}$. In eight experiments with $P s$ putida the number of colony forming units per $\mathrm{ml}$ elutant ranged from $1.0 \times 10^{7}$ to $4.6 \times 10^{7}$ with a 
mean of $2.4 \times 10^{7}$. The lowest figures obtained for the three organisms were subsequently used as the control counts upon which log reductions in count achieved by particular cleaning and disinfection procedures were based.

Disinfection can be achieved by mechanical removal of organisms, heat or chemical destruction of organisms in situ, or a combination of both. Mechanical removal of test organisms from the biopsy channel of the fibrescope was investigated by contaminating the channel as previously described, aspirating $200 \mathrm{ml}$ or $500 \mathrm{ml}$ volumes of sterile distilled water, Cidex, or buffered hypochlorite at room temperature up through the channel, and enumerating survivors in elutant flushed down the channel immediately afterwards. The log reductions in count achieved by each treatment are given in Table 1. Aspiration of

Table 1 Mechanical removal of organisms from $a$ fibrescope biopsy channel by aspiration of liquids up through the channel at $23 \pm 1^{\circ} \mathrm{C}$

\begin{tabular}{|c|c|c|c|c|}
\hline \multicolumn{2}{|l|}{ Treatment } & \multicolumn{3}{|c|}{ Log reductions ${ }^{*}$ in count of: } \\
\hline Liquid & Volume $(\mathrm{ml})$ & Ps putida & $M$ fortuitum & $\begin{array}{l}\text { B subtilis } \\
\text { spores }\end{array}$ \\
\hline $\begin{array}{l}\text { Distilled water } \\
\text { Hypochlorite } \dagger \\
\text { Hypochlorite } \dagger \\
\text { Cidex } \\
\text { Cidex } \\
\text { Maximum reduct }\end{array}$ & $\begin{array}{l}500 \\
200 \\
500 \\
200 \\
500 \\
\text { tion possible }\end{array}$ & $\begin{array}{l}1 \cdot 6 \\
5 \cdot 8 \\
6 \cdot 7 \\
6 \cdot 0 \\
6 \cdot 7 \\
7 \cdot 0\end{array}$ & $\begin{array}{l}2 \cdot 4 \\
3 \cdot 5 \\
3 \cdot 2 \\
2 \cdot 7 \\
3 \cdot 0 \\
4 \cdot 0\end{array}$ & $\begin{array}{l}4 \cdot 0 \\
3 \cdot 5 \\
4 \cdot 0 \\
1 \cdot 1 \\
2 \cdot 0 \\
4 \cdot 0\end{array}$ \\
\hline
\end{tabular}

* Mean of 4-12 experiments.

$\dagger 100 \mathrm{ppm}$ av $\mathrm{Cl}$ at $\mathrm{pH} \mathrm{7.6.}$

$500 \mathrm{ml}$ water was extremely effective in flushing out spores of $B$ subtilis, very effective in flushing out vegetative cells of $M$ fortuitum, but relatively ineffective in flushing out vegetative cells of Ps putida, presumably reflecting the different adhesive properties of the organisms. Aspiration of $500 \mathrm{ml}$ buffered hypochlorite was extremely effective in flushing out and/or killing spores of $B$ subtilis, and also very effective against vegetative cells of $M$ fortuitum and $P$ s putida, reflecting differences in both sensitivity and adhesive properties of the organisms. Aspiration of $500 \mathrm{ml}$ Cidex was much less effective than buffered hypochlorite in flushing out and/or killing spores of $B$ subtilis, but like the hypochlorite was very effective against vegetative cells of $M$ fortuitum and $P$ s putida. The failure of aspirated water to flush out more than a small proportion of Ps putida demonstrates the need for effective chemical disinfection because pseudomonads thrive in endoscopy equipment inadequately disinfected and left wet between sessions. ${ }^{2}$ The results of experiments to determine the effect on test organisms of filling the biopsy channel with buffered hypochlorite and leaving it for increasing periods of time is given in Table 2 . It can be seen that a ten-minute soak in buffered
Table 2 Chemical destruction of organisms in a fibrescope biopsy channel by soaking in hypochlorite solutions at $23 \pm 1^{\circ} \mathrm{C}$

\begin{tabular}{|c|c|c|c|c|c|c|}
\hline \multirow{3}{*}{$\begin{array}{l}\text { Soak } \\
\text { time } \\
\text { (min) }\end{array}$} & \multicolumn{6}{|c|}{ Log reductions* in count achieved with } \\
\hline & \multicolumn{2}{|l|}{ Ps putida } & \multicolumn{2}{|c|}{$M$ fortuitum } & \multicolumn{2}{|c|}{ B subtilis spores } \\
\hline & 100 ppm $\dagger$ & $200 \mathrm{ppm}$ & $100 \mathrm{ppm}$ & $200 \mathrm{ppm}$ & $100 \mathrm{ppm}$ & $200 \mathrm{ppm}$ \\
\hline 1 & $4 \cdot 0$ & $5 \cdot 0$ & $3 \cdot 0$ & $4 \cdot 0$ & - & - \\
\hline 2 & $3 \cdot 0$ & $5 \cdot 0$ & - & - & - & - \\
\hline 3 & - & $7 \cdot 0$ & 3.5 & 2.5 & - & 4.0 \\
\hline 5 & $7 \cdot 0$ & 7.0 & - & - & $3 \cdot 3$ & 4.0 \\
\hline 10 & $7 \cdot 0$ & 7.0 & $4 \cdot 0$ & $4 \cdot 0$ & 4.0 & 4.0 \\
\hline
\end{tabular}

* Mean of 3 experiments.

†Hypochlorite solution containing $100 \mathrm{ppm}$ av $\mathrm{Cl}$ buffered at pH 7.6.

hypochlorite of $100 \mathrm{ppm}$ av $\mathrm{Cl}$ killed all the test organisms. Next, the effect of a five- or ten-minute soak in hypochlorite of $100 \mathrm{ppm}$ av $\mathrm{Cl}$ followed by aspiration of $50 \mathrm{ml}$ fresh hypochlorite up through the channel was investigated. With $P s$ putida and $B$ subtilis spores a five-minute presoak was adequate, but with $\boldsymbol{M}$ fortuitum (which forms clumps) a tenminute presoak was required to eliminate the test organisms.

In practice, the organisms contaminating the inside of a fibrescope biopsy channel following an endoscopy procedure are likely to be coated with organic matter. Furthermore, contaminating material in the channel may be allowed to dry out before cleaning and disinfection procedures are performed. Hence, in final experiments, the effectiveness of a combination of cleaning and disinfection on test organisms suspended in horse serum and left in the biopsy channel overnight (as previously described) was investigated. Approximately $10^{6}$ test organisms, either $B$ subtilis spores or $M$ fortuitum, were deposited in the channel by the contamination procedure. Five experiments were performed using $B$ subtilis spores and five using $M$ fortuitum. In all cases the combination of cleaning and disinfection using buffered hypochlorite of $100 \mathrm{ppm}$ av $\mathrm{Cl}$ effected at least a 5-log reduction in count of the test organisms. It is concluded, therefore, that a combination of thorough cleaning followed by chemical disinfection with buffered hypochlorite constitutes a very effective method of disinfecting the biopsy channel of a fibrescope, even if the contaminating organisms are relatively resistant to chemical disinfection, and are coated in partially dried organic matter.

\section{CORROSION STUDIES}

Strong hypochlorite solutions are noted for being corrosive to many metals and destructive to various other materials such as rubber. Hence experiments were performed to assess the corrosive properties of 
hypochlorite solutions used in the present studies against various metals and fibrescope components. The effects of unbuffered hypochlorite of $2000 \mathrm{ppm}$ av $\mathrm{Cl}$ at $\mathrm{pH} 11 \cdot 4$, and buffered hypochlorite of 100 ppm av $\mathrm{Cl}$ at $\mathrm{pH} 7.8$ on 10 different metal wires were investigated by immersing short lengths of wire in $15 \mathrm{ml}$ volumes of hypochlorite in universal bottles and assessing any corrosion after three days, two weeks and three months. Detailed results are given by Death ${ }^{8}$ and are summarised in Table 3 . Neither solution had any apparent corrosive effect on either stainless steel or platinum. With regard to the other metals, the buffered dilute hypochlorite solution was far less corrosive than the unbuffered concentrated hypochlorite solution. Galvanised iron, spring steel and phosphobronze were all rapidly and seriously corroded by the concentrated solution. However, in the dilute solution corrosion was markedly reduced; galvanised iron and phosphobronze were virtually unaffected even after three months immersion. Thus, the buffered dilute hypochlorite solution has two great advantages over the unbuffered concentrated solution; it is not only much more rapidly sporicidal but is also much less corrosive.

Table 3 Corrosion of metal wires by hypochlorite solutions at $25^{\circ} \mathrm{C}$

\begin{tabular}{|c|c|c|c|c|c|c|}
\hline \multirow[t]{2}{*}{ Metal } & \multicolumn{3}{|c|}{$100 \mathrm{ppm}$ av $\mathrm{Cl} \mathrm{pH} 7 \cdot 8$} & \multicolumn{3}{|c|}{$2000 \mathrm{ppm}$ av Cl pH 11.4} \\
\hline & 3 days & $2 w k$ & 3 months & 3 days & $2 w k$ & 3 months \\
\hline Stainless steel & - & - & - & - & - & - \\
\hline Platinum & - & - & - & - & - & - \\
\hline Nichrome (1) & - & + & + & \pm & \pm & \pm \\
\hline Nichrome (2) & - & \pm & \pm & \pm & $\overline{ \pm}$ & \pm \\
\hline Copper & \pm & \pm & \pm & + & + & + \\
\hline Tinned copper & + & + & + & \pm & + & + \\
\hline Brass & - & - & \pm & + & + & + \\
\hline Galvanised iron & - & \pm & \pm & ++ & $+t$ & $+t$ \\
\hline Spring steel & + & + & + & ++ & $+t$ & ++ \\
\hline Phosphobronze & - & \pm & \pm & ++ & ++ & ++ \\
\hline
\end{tabular}

- no apparent corrosion.

+ slight to moderate corrosion.

++ severe corrosion.

In final experiments the possible corrosive effects of buffered hypochlorite solutions containing 100 , 200 and $500 \mathrm{ppm}$ av $\mathrm{Cl}$ on various fibrescope materials was investigated. The materials were immersed for up to $16 \mathrm{wk}$ at room temperature in solutions freshly prepared and changed daily. During each change the materials were examined visually for any sign of corrosion. Polyurethane is used for the outer coating of the insertion tube of flexible fibrescopes. It usually has a high gloss and is black with white markings. Hypochlorite solution of $500 \mathrm{ppm}$ av $\mathrm{Cl}$ caused the polyurethane to blister badly within seven days immersion. Blistering did not occur with solutions of 100 and $200 \mathrm{ppm}$ av $\mathrm{Cl}$ but the gloss disappeared, the white markings yellowed slightly and a white deposit formed after prolonged immersion. The available chlorine content of solutions diminished rapidly (Fig 2). However, in

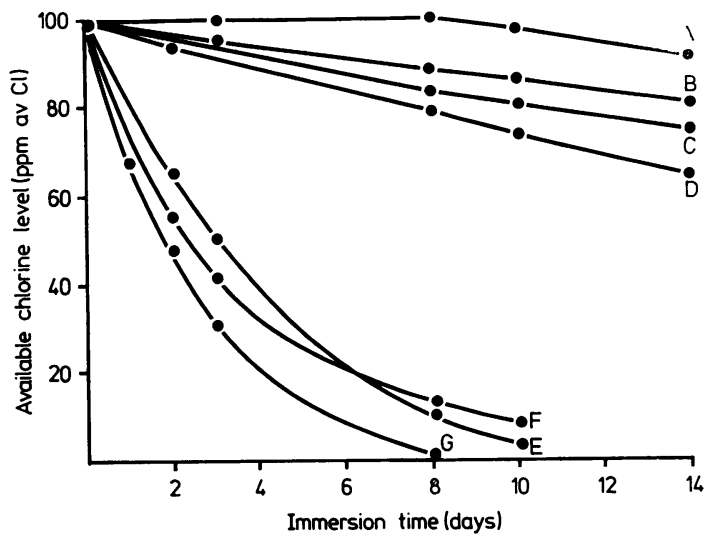

Fig. 2. Reductions of available chlorine in hypochlorite solutions of initial concentration $100 \mathrm{ppm}$ av Cl at $p H 7 \cdot 6$, following immersion of fibrescope components at $23^{\circ} \mathrm{C}$. $\mathrm{A}=$ polythene; $B=$ Teflon; $C=$ control, no component immersed; $D=$ stainless steel, glass lens and Araldite; $E=$ glass coverslips and Araldite; $F=$ rubber; $G=$ polyurethane.

other experiments, daily immersion of polyurethane in a solution of $100 \mathrm{ppm}$ av $\mathrm{Cl}$ for an hour followed by rinsing in water and drying caused no damage in 32 days' treatment. Control samples immersed in tap water showed no signs of corrosion over test periods. Rubber is used in valves and as a flexible coat over the distal bending section of the insertion tube. Immersion for several weeks in solutions of 200 and $500 \mathrm{ppm}$ av $\mathrm{Cl}$ caused stickiness of the rubber associated with loss of available chlorine from the solutions. Araldite, a two part epoxy resin, is used as a cement for lenses. Microscope slides stuck together at right angles with Araldite were used as test pieces. ${ }^{8}$ Freshly set Araldite was not visibly affected by hypochlorite although losses in available chlorine from the solutions occurred (Fig. 2). Distal tips of insertion tubes made of stainless steel with glass lenses cemented in situ were not visibly affected by the hypochlorite solutions and losses in available chlorine were not significantly greater than in control solutions. Hence with these test pieces there was no evidence of any reaction between the epoxy resin lens cement and the available chlorine. Teflon, which is used for biopsy channels, and polythene, which is used for air and water channels, were not affected by the hypochlorite solutions and losses in available chlorine were not significant. Thus, only polyurethane and rubber showed visible signs of corrosion after lengthy immersion in the hypochlorite solutions. The oesophago- 
fibrescope used for testing buffered low concentration hypochlorite solutions against test organisms in the biopsy channel was not affected by the solutions over the 12-month research period. In these tests short periods of immersion were employed and the instrument was washed and rinsed after use.

It is concluded from these results that buffered hypochlorite solution of $100-200 \mathrm{ppm}$ av $\mathrm{Cl}$ will not damage the biopsy or air/water channels of a fibrescope whether or not it is aspirated/blown straight through the channels or left in them to soak. The outer coating of an insertion tube is susceptible to damage by buffered hypochlorite of $500 \mathrm{ppm}$ av $\mathrm{Cl}$. However, a few minutes contact with a solution of $100 \mathrm{ppm}$ av $\mathrm{Cl}$ is unlikely to cause any damage if the insertion tube is subsequently rinsed in water. Long term exposure of the insertion tube coating to hypochlorite may result in tackiness of the rubber sleeveat the distal tip, loss of gloss of the polyurethane and yellowing of the white markings.

\section{Discussion}

In recent years many incidents and outbreaks of infection associated with endoscopy have been reported. Three sources of organisms are important: the patient's own flora, pathogens transmitted from one patient to another during an endoscopy list, and opportunistic pathogens which have multiplied on equipment left wet between lists. ${ }^{2}$ Sterilisation of endoscopy equipment will not eliminate endogenous infections. In bronchoscopy, for example, it is possible that potential pathogens present in the nasopharynx will be carried past the natural defence mechanisms to the lower respiratory tract. ${ }^{11}$ In one probable case ${ }^{12}$ fibreoptic bronchoscopy with endobronchial biopsy of an elderly debilitated man was rapidly followed by development of fatal pneumococcal bronchopneumonia with septicaemia and meningitis. Cleaning and disinfection of endoscopes between patients on a list should prevent transmission of pathogens from one patient to another. Various pathogens have been transmitted on inadequately decontaminated fibrescopes including Salmonella typhi, ${ }^{13} S$ typhimurium, ${ }^{14} S$ agona, ${ }^{15}$ $M$ tuberculosis, ${ }^{16}$ Serratia marcescens ${ }^{17}$ and $P S$ aeruginosa. ${ }^{18}$ The possibility of transmission of hepatitis B virus is worrying. Available evidence for gastroscopes ${ }^{219-21}$ suggests that the risk is minimal if thorough cleaning followed by disinfection is carried out. However, the infective dose of any pathogen will depend on many factors including the pathogen concerned, the portal of entry-for example, whether peroral route or percutaneous route, and how severely the patient is compromised. It has been shown ${ }^{22}$ that $\mathrm{HBs} A g$ serum is infective in a one in ten million dilution when given parenterally. Hence cleaning followed by sterilisation is indicated for endoscopes introduced through surgical incisions-for example, laparoscopes. At the end of a list endoscopes and ancillary equipment must be thoroughly cleaned, disinfected or sterilised and stored dry. Before commencement of the next list endoscopes and accessories should be redisinfected in case opportunistic pathogens such as Pseudomonas spp have proliferated in damp sites. Greene et al $^{18}$ described an outbreak in which three leukaemic patients acquired exogenous $P$ s aeruginosa during oesophagoscopy. Two of the patients who were severely granulocytopenic died of Pseudomonas septicaemia after endoscopy in which mucosal biopsy specimens were taken. The third patient did not develop any clinical illness although the Pseudomonas was isolated from her stool following endoscopy in which biopsy specimens were not taken.

Put into perspective, the number of endoscopy associated infections reported is minute compared with the number of endoscopies performed. There are many reasons for this. Transmission of potential pathogens on endoscopes may result in colonisation ${ }^{2}$ or transient bacteraemia ${ }^{23}$ instead of infection, due to the capacity of the local inflammatory response, in the uncompromised patient, to limit bacterial invasion through mucosal breaks, and of the reticuloendothelial system to clear low grade bacteraemia. ${ }^{18}$ Infections may not be recognised or reported. Decontamination procedures may kill or dilute out pathogens to non-infective levels for non-compromised patients. However, in the compromised patient endoscopy, particularly with biopsy, carries the risk of infection with either endogenous or exogenous flora. The latter can be eliminated by sterilising the instrument before use.

Ideally all endoscopes should be cleaned and then sterilised before use. However, as there is no quick method of sterilising endoscopes, the adequacy of disinfection methods must be considered. Three categories of endoscope may be distinguished on the basis of their requirement for sterilisation or disinfection. It is recognised ${ }^{24}$ that sterilised equipment is essential for all procedures involving a break in the skin or mucous membrane. Hence the first category-sterilisation essential-applies to endoscopes introduced into normally sterile sites through surgical incisions-for example, laparoscopes and arthroscopes. Infection with spore-bearing organisms is most unlikely to occur through contact of contaminated equipment with intact mucous membranes. Disinfection of such equipment is therefore usually adequate although sterilisation is always preferable, particularly when a normal sterile site is involved. ${ }^{24}$ Hence the second category-sterilisation preferable 
but disinfection usually adequate-applies to endoscopes introduced into normally sterile sites through natural orifices-for example, cystoscopes. In practice sporing bacteria rarely infect the urinary tract and their transmission by cystoscopes is unlikely. ${ }^{25}$ The third category-disinfection usually adequate-applies to endoscopes introduced into normally contaminated sites through contaminated natural orifices-for example, colonoscopes. The above categorisation applies to endoscopes when used for observation only. If biopsy specimens are needed then both the biopsy channel and forceps require sterilisation irrespective of the endoscope category.

Various chemical disinfectants have been suggested for decontamination of fibrescopes including benzalkonium chloride, ${ }^{26}$ hexachlorophene followed by alcoholic povidone-iodine ${ }^{27}$ and glutaraldehyde ${ }^{28}$ none of which are rapidly sporicidal. The buffered hypochlorite solution described above is very rapidly sporicidal and hence is a potential sterilant. It is cheap and simple to prepare. A solution containing $100 \mathrm{ppm}$ av $\mathrm{Cl}$ can be made by adding 1 $\mathrm{ml}$ of a $1 \%$ solution of sodium hypochlorite (which contains $10000 \mathrm{ppm}$ av Cl) to $99 \mathrm{ml}$ phosphate buffer solution. Hence it can be easily prepared fresh at the start of an endoscopy session and any left at the end discarded. The microbicidal activity of buffered hypochlorite was tested against spores of $B$ subtilis and vegetative cells of $M$ fortuitum and Ps putida. Spores of Bsubtilis and vegetative cells of $M$ fortuitum were selected as test organisms because of their relative resistance to chemical disinfection, established in previous studies. ${ }^{4}$ Ps putida was chosen because of the clinical relevance of pseudomonads. All three organisms were rapidly killed by the disinfectant. The results obtained with $B$ subtilis demonstrate that even large numbers of resistant bacterial spores can be killed by a few minutes soak in the disinfectant.

Hypochlorite solutions usually suffer the disadvantages of being prone to inactivation by organic matter and of being corrosive to many metals and materials. These aspects of buffered hypochlorite solutions were therefore tested. Heavy inocula of test organisms suspended in horse serum and left overnight to dry out partially in the biopsy channel of a fibrescope were found to be readily removed or killed by a procedure involving mechanical cleaning of the channel followed by disinfection with buffered hypochlorite. It was therefore concluded that as long as thorough cleaning precedes use of buffered hypochlorite then inactivation by organic matter is not a problem. With regard to corrosion, the fibrescope used in laboratory tests which lasted over a year showed no sign of damage on completion of research. However, the experiments carried out on various fibrescope components showed that continual immersion of an insertion tube for a few days in buffered hypochlorite of $500 \mathrm{ppm}$ av $\mathrm{Cl}$ or for longer periods in a solution of $200 \mathrm{ppm}$ av $\mathrm{Cl}$ could result in serious damage to either the polyurethane coat or the rubber sleeve at the distal end. In contrast, daily immersion of polyurethane in a solution of $100 \mathrm{ppm}$ av $\mathrm{Cl}$ for an hour followed by rinsing in water and drying caused no damage in 32 days treatment. Perhaps the corrosive effects could be reduced by addition of an anticorrosion agent to the buffered hypochlorite solution, or by some treatment of the polyurethane and rubber components by the manufacturer. We conclude that it is safe to aspirate/ blow a buffered hypochlorite solution of 100-200 ppm av $\mathrm{Cl}$ from a reservoir into the inner channels and leave it to soak for 5-10 min (or much longer) which is sufficient time for the disinfectant to kill most, if not all, of any bacteria present.

However, it should not be assumed that total immersion of an insertion tube in a buffered hypochlorite solution of $100-200 \mathrm{ppm}$ av $\mathrm{Cl}$ for $10 \mathrm{~min}$ followed by rinsing in water is safe for routine use. Our fibrescope was not damaged after a year of such treatment but the onus is on prospective users to test solutions on their instruments. Although our experiments were conducted on a fibrescope, buffered hypochlorite could prove useful for disinfecting telescopes. Laparoscopes and arthroscopes should be sterilised before use. Cleaning followed by 5-10 min immersion in buffered hypochlorite would probably eliminate all bacteria and yeasts ${ }^{6}$ but the activity against other types of microbe has not been tested, and corrosion studies on telescopes have not been done.

Several aspects of the potential use of buffered hypochlorite solutions remain to be investigated. The activity against viruses, moulds, and parasites is unknown. The addition of a detergent to a buffered hypochlorite solution may increase its antimicrobial activity by decreasing the surface tension and increasing the "wetting ability". The addition of an anticorrosion agent to a solution may significantly reduce its corrosive properties. Many items other than fibrescopes which are either thermolabile or require rapid effective disinfection may be suitable for treatment with buffered hypochlorite solutions but so far none has been investigated.

We thank KeyMed Ltd, Southend-on-Sea, England, for the loan of the oesophago-fibrescope and the gift of fibrescope components which were used in our studies. 


\section{References}

${ }^{1}$ Chang FM, Sakai Y, Ashizawa S. Bacterial pollution and disinfection of the colonofiberscope. 2. Ethylene oxide gas sterilisation. Am J Dig Dis 1973;18:951-8.

2 Axon ATR, Cotton PB, Phillips I, Avery SA. Disinfection of gastrointestinal fibre endoscopes. Lancet 1974 ; i :656-8.

${ }^{3}$ Elford B. Care and cleansing of the fiberoptic bronchoscope Chest 1978 ;3, suppl: 761-3.

4 Kelsey JC, MacKinnon IH, Maurer IM. Sporicidal activity of hospital disinfectants. J Clin Pathol 1974;27: 632-8.

${ }^{5}$ Coates D, Death JE. Sporicidal activity of mixtures of alcohol and hypochlorite. J Clin Pathol 1978;31:148-52.

${ }^{6}$ Death JE, Coates D. Effect of $\mathrm{pH}$ on sporicidal and microbicidal activity of buffered mixtures of alcohol and sodium hypochlorite. J Clin Pathol 1979;32:148-53.

${ }^{7}$ Beeby MM, Whitehouse CE. A bacterial spore test piece for the control of ethylene oxide sterilization. $J$ Appl Bacteriol 1965;28:349-60.

${ }^{8}$ Death JE. Sporicidal activity of alcohol-hypochlorite mixtures and hypochlorite solutions with particular reference to fibre-optic endoscope disinfection. PhD thesis. Guildford: University of Surrey, 1979.

${ }^{9}$ Coates D. Kelsey-Sykes capacity test: origin, evolution and current status. Pharmaceutical J 1977;219:402-3.

${ }^{10}$ Miles AA, Misra SS, Irwin JO. The estimation of the bactericidal power of the blood. J Hyg 1938;38:732-49.

${ }^{11}$ Pereira W, Kovnat DM, Anees Khan M, Iacovino JR, Spivack ML, Snider GL. Fever and pneumonia after flexible fiberoptic bronchoscopy. Am Rev Respir Dis 1975;112:59-64.

12 Beyt BE, King DK, Glew RH. Fatal pneumonitis and septicemia after fiberoptic bronchoscopy. Chest 1977;72: 105-7.

${ }^{13}$ Dean AG. Transmission of Salmonella typhi by fiberoptic endoscopy. Lancet 1977; ii:134.

${ }^{14}$ Beecham HJ, Cohen ML, Parkin WE. Salmonella typhimurium transmission by fiberoptic upper gastrointestinal endoscopy. JAMA 1979;241:1013-5.

${ }^{15}$ Schliessler KH, Rozendaal B, Taal C, Meawissen SGM. Outbreak of Salmonella agona infection after upper intestinal fibreoptic endoscopy. Lancet 1980;ii:1246.

${ }^{16}$ Leers WD. Disinfecting endoscopes: how not to transmit
Mycobacterium tuberculosis by bronchoscopy. Can Med Assoc J 1980;123:275-83.

${ }^{17}$ Webb SF, Vall-Spinosa A. Outbreak of Serratia marcescens associated with the flexible fibre bronchoscope. Chest 1974;68:703-8.

18 Greene WH, Moody M, Hartley R, Effman E, Aisner J, Young VM, Wiernik PH. Esophagoscopy as a source of Pseudomonas aeruginosa sepsis in patients with acute leukemia: the need for sterilization of endoscopes. Gastroenterology 1974;67:912-9.

19 Morris IM, Cattle DS, Smits BJ. Endoscopy and transmission of hepatitis B. Lancet 1975; ii:1152.

${ }^{20}$ McDonald GB, Silverstein FE. Can gastrointestinal endoscopy transmit hepatitis B to patients? Gastrointest Endosc 1976;22:168-70.

${ }^{21}$ McClelland DBL, Burrell CJ, Tonkin RW, Heading RC. Hepatitis B: absence of transmission by gastrointestinal endoscopy. Br Med J 1978;i:23-4.

22 Barker LF, Shulman NR, Murray R, Hirschman RJ, Ratner F, Diefenbach WCL, Geller HM. Transmission of serum hepatitis. JAMA 1970;211:1509-12.

${ }^{23}$ LeFrock JL, Ellis CA,Turchik JB, et al. Transient bacteremia associated with sigmoidoscopy. N Engl J Med 1973;289: 467-9.

${ }^{24}$ Lowbury EJL, Ayliffe GAJ, Geddes AM, Williams JD, eds. Control of hospital infection. London: Chapman and Hall 1975.

${ }^{25}$ Gillespie WA, Mitchell JP. Sterilisation and disinfection of cystoscopes. Notes on sterilisation No 1. Association of Clinical Pathologists, 1967.

${ }^{26} \mathrm{Kato} \mathrm{H}$. Experimental study for rapid sterilization of the flexible fiberoptic bronchoscope. Chest 1974;66:723-4.

27 Suratt PM, Gwaltney JM, Sande MA. A rapid method of disinfecting the bronchofiberscope. Am Rev Respir Dis 1976; $114: 1198-200$.

${ }^{28}$ Carr-Locke DL, Clayton P. Disinfection of upper gastrointestinal fibreoptic endoscopy equipment: an evaluation of a cetrimide chlorhexidine solution and glutaraldehyde. Gut 1978;19:916-22.

Requests for reprints to: Dr D Coates, Public Health Laboratory, Preston Infirmary, Meadow Street, Preston, Lancashire PR1 6PS, England. 